UDC 327

Submitted: 27.08 .2020

LBC 66.4(0)

Accepted: 30.09 .2020

\title{
THE INFLUENCE OF MODERN INTERNATIONAL TERRORISM ON THE MAIN MEGATRENDS OF MODERN WORLD POLITICS
}

\author{
Hasan R. Jabbarinasir \\ MGIMO University MFA Russia, Moscow, Russian Federation; \\ Institute for Social and Cultural Studies of the Ministry of Science, Research and Technology, Tehran, Iran
}

\begin{abstract}
Introduction. The article analyzes the influence of modern terrorism on two megatrends of contemporary world politics - globalization and democratization, which are linked with three levels of political organization of modern world - the Westphalian system, the system of interstate relations and the political system of states. Methods and materials. The methodology of systems approach is applied which allows identifying the variety of factors of mutual influence between terrorism and the selected trends. A simplified method of constructing a forecasting scenario is used, which provides a description of the influence of terrorism on the dynamics of the development of globalization and democratization in the future. The author relies on the ideas of a cyclical approach, according to which "upward" and "downward" stages are inherent characteristic of social and political processes. To understand the influence of terrorism as a factor of such cycles in the development of considered megatrends, scientific and analytical materials of Russian, Western and Iranian researchers are used. Analysis. It has been established that modern international terrorism uses the uneven distribution of benefits from globalization and its unifying characteristics in the sphere of culture and social relations in its destructive ideology and practice. As a result, globalization in the least developed countries is perceived in a negative way, and the risks of local rollbacks for this phenomenon remain. Long-term recommendations are proposed to improve the current situation. A scenario of anti-terrorist struggle, its state and prospects, and the dynamics of the two selected megatrends in the context of those scenarios have been developed. Results. It is concluded that terrorism is a significant negative factor for globalization and democratization. The first feels the influence of terrorism at the local level and it is unlikely to become a de-globalizing force, while the direct or indirect influence of international terrorism on the dynamic of democratization waves can be more significant.

Key words: megatrends, world politics, international terrorism, extremism, globalization, democratization.

Citation. Jabbarinasir H.R. The Influence of Modern International Terrorism on the Main Megatrends of Modern World Politics. Vestnik Volgogradskogo gosudarstvennogo universiteta. Seriya 4. Istoriya. Regionovedenie. Mezhdunarodnye otnosheniya [Science Journal of Volgograd State University. History. Area Studies. International Relations], 2021, vol. 26, no. 3, pp. 22-33. (in Russian). DOI: https://doi.org/10.15688/ jvolsu4.2021.3.3
\end{abstract}

\section{ВЛИЯНИЕ СОВРЕМЕННОГО МЕЖДУНАРОДНОГО ТЕРРОРИЗМА НА ОСНОВНЫЕ МЕГАТРЕНДЫ СОВРЕМЕННОЙ МИРОВОЙ ПОЛИТИКИ}

\section{Хасан Реза Джаббаринасир}

Московский государственный институт международных отношений (университет) МИД России, г. Москва, Российская Федерация;

Институт социальных и культурных исследований Министерства науки, исследований и технологий ИРИ, г. Тегеран, Иран

Аннотация. Введение. В статье анализируется влияние современного терроризма на два мегатренда современной мировой политики - глобализацию и демократизацию, которые связаны с тремя уровнями 
политической организации современного мира - Вестфальской системой, системой межгосударственных отношений и политической системой государств. Mетоды и материаль. Применяется методология системного анализа, позволяющая выявить многообразие факторов взаимовлияния между терроризмом и рассматриваемыми трендами. Используется симплифицированный метод построения прогнозного сценария, предусматривающий описание влияния терроризма на динамику развития глобализации и демократизации в будущем. Автор опирается на идеи цикличного подхода, согласно которому для динамики социальнополитических процессов характерны «повышательные» и «понижательные» стадии. Для осмысления влияния терроризма в качестве фактора таких циклов в развитии выбранных мегатрендов привлечены научноаналитические материалы российских, западных и иранских исследователей. Анализ. Установлено, что современный международный терроризм использует неравномерность распределения благ от глобализации и ее унифицирующие характеристики в сфере культуры и социальных отношений в своей деструктивной идеологии и практике, в результате чего глобализация в наименее развитых странах воспринимается в негативном ключе, а риски локальных откатов для данного феномена сохраняются. Предложены рекомендации долгосрочного характера по улучшению нынешней ситуации. Разработан сценарий антитеррористической борьбы, ее состояние и перспективы, а также динамика двух выбранных мегатрендов при каждом из них. Результаты. Сделан вывод о том, что терроризм является значительным негативным фактором для глобализации и демократизации. Для глобализации влияние терроризма ощущается на локальном уровне и вряд ли станет де-глобализирующей силой, тогда как на направление «волн» демократизации непосредственно или опосредованно влияние международного терроризма оказывается более значительным.

Ключевые слова: мегатренды, мировая политика, международный терроризм, экстремизм, глобализация, демократизация.

Цитирование. Джаббаринасир Х. Р. Влияние современного международного терроризма на основные мегатренды современной мировой политики // Вестник Волгоградского государственного университета. Серия 4, История. Регионоведение. Международные отношения. - 2021. - T. 26, № 3. - С. 22-33. - DOI: https:// doi.org/10.15688/jvolsu4.2021.3.3

Введение. Современный терроризм это сложный социально-политический феномен, который ввиду своей гибкости и постоянной трансформации используемых методов, идеологических мотивов и деструктивных практик пока не поддается должному теоретическому осмыслению. Более того, в академических и политических кругах нет единого определения термина «терроризм», которое поддерживалось бы всеми государствами, международными институтами и стало бы основой для международного сотрудничества по борьбе с этим явлением. Определение феномена терроризма не является проблемой исключительно академического сообщества, на практике, в зависимости от того, как определяется терроризм, принимаются меры по борьбе с ним, в том числе и на глобальном уровне.

В настоящей работе автор использует определение известных специалистов по проблематике мировой политики Дж. Бейлиса и С. Смита, которые подразумевают под терроризмом организованное незаконное использование насилия или угрозу его применения в международном (транснациональном) масш- табе против группы людей или конкретных индивидуумов, а также их имущества для достижения политических целей, запугивания оппонентов и разжигания массового недовольства в обществе [14]. Учитывая, что современный терроризм носит транснациональный характер, в настоящей статье термины «терроризм» и «международный терроризм» во многом равнозначны. Автор уточняет, что идеология современного терроризма является преимущественно религиоцентричной, поэтому под международным терроризмом в данной работе подразумевается религиозноисламистский терроризм. Использование понятия «экстремизм» в соседстве с «терроризм»-ом автором аргументируется тем, что эти два феномена в современном контексте преимущественно выступают двумя сторонами одной медали. Опираясь на особое, ваххабитское - по сущности насильственное - толкование исламских учений, они стремятся к тому, чтобы «вешать такфиристские ярлыки» не только на немусульман, но и на исповедующих ислам людей. Распространение такой идеологии по всему миру ставит на повестку дня борьбу не только с международным тер- 


\section{ПРОГНОЗНЫЕ СЦЕНАРИИ ПОЛИТИЧЕСКИХ ТРАНСФОРМАЦИЙ}

роризмом, но и с религиозным экстремизмом, которая должна вестись как «жесткими» методами, так и «мягкими».

Сегодня, на этапе предкризисного состояния Вестфальской системы международных отношений, террористические группировки получили возможность для реализации своей стратегии, заключающейся в переустройстве мира на иных, по мнению экстремистов, более справедливых началах. Такая совокупность проблем в международных отношениях представляет собой некий «идеальный шторм», который может стать катализатором непредсказуемых сдвигов в системе политической организации мира. Такое утверждение подводит нас к проблематике мегатрендов - долгосрочных и крупномасштабных процессов, определяющих качественное содержание эволюции мировой политики [8], и влияния на них международного терроризма.

Термин «мегатренды» впервые появился в опубликованной в 1982 г. одноименной книге американского футуролога Дж. Нейсбитта. Автор исследовал «основные направления движения, которые определяют облик и суть» изменяющегося американского общества [24]. С тех пор подходов к выделению мегатрендов в исследовательском дискурсе появилось множество; то, что для одних выступает большим трендом (например, прогресс инфокоммуникационных технологий) [2], для других является лишь фоном для развития других мегатрендов [7]. Однако, несмотря на вариативность трактовок в академических работах, главным критерием определения таких трендов представляется степень их нынешнего воздействия на векторы глобального развития и перспективы усиления его влияния в будущем.

Автор настоящей работы считает, в общих чертах мегатренды имеют три особенности:

- они возникают постепенно, однако по мере усиления их влияние может продолжаться не менее трех десятилетий;

- они оказывают влияние на самые различные аспекты жизни государства, общества в целом и отдельного человека в частности;

- они географически не привязаны к конкретным территориям, однако могут наибо- лее ярко проявляться в том или ином географическом пространстве.

Опираясь на представленные выше дефиниции, можно сказать, что в какой-то степени и процессы, связанные с терроризмом, тоже могут быть представлены как мегатренд. Так, рост угрозы терроризма в некоторых научных и прогнозно-сценарных исследованиях называется мегатрендом современного мира $[2 ; 19]$. Логика такой позиции во многом исходит из артикулируемого в исследовательском дискурсе и наблюдаемого на практике «восточного» протеста против навязывания всему миру западных ценностей, нарастающего «порабощения» развивающихся стран более развитыми государствами. Такие социально-экономические и политические фрустрации генерируют мегатренд - усиление терроризма на религиозно-политической почве. Однако в настоящей работе автор считает терроризм не мегатрендом, а фактором изменения содержания/векторов развития таких трендов.

Цель настоящей статьи заключается в исследовании влияния международного терроризма на основные мегатренды современной мировой политики. В качестве таких больших трендов автор выбирает глобализацию и демократизацию. Обосновывается такая выборка тем, что обозначенные мегатренды оказывают влияние на динамику эволюции трех уровней политической организации современного мира - Вестфальской системы, системы межгосударственных отношений и политической системы государств, и изучение влияния терроризма на эти уровни имеет высокую научно-прикладную значимость.

Методология исследования. В представленной работе автор опирается на идеи цикличного подхода, поскольку осмысление нелинейной динамики развития обозначенных выше мегатрендов и влияния терроризма на них требует применения теоретической альтернативы симплифицированным линеарнопрогрессистским моделям развития современных мирополитических процессов. Концепт цикличности является достаточно распространенным средством теоретического анализа регулярных изменений, хотя внимание к нему носит преимущественно конъюнктурный, а не фундаментальный характер [13]. 
Проблематика цикличности в политической науке обсуждается в целом ряде работ. В. Пантин и В. Лапкин предлагают рассматривать политический процесс, основанный на кондратьевских волнах подъема и спада экономики [10], М. Калдор пишет о трансформации преобразовательной роли насилия/войны и появлении новых агентов изменения (agents of change) [21], В. Ильин циклически-волновую методологию рассматривает в контексте синергетики, делающей акцент на чередовании феноменов порядка и хаоса [6]. Последняя исследовательская позиция наиболее близка для нас, поскольку в нее вписывается цикличность в мировой политике с двумя фазами: цикла эволюции и революционного цикла (фазы хаотизации). Первый период способствует подъему в развитии, а во время второй фазы происходят спад и кризисы. Последовательность чередования порядка и хаоса, таким образом, представляется достаточно естественным ходом развития социально-политических процессов, и в этом контексте актуальным всегда остается вопрос осмысления катализаторов/факторов таких трансформаций.

Автор настоящей статьи попытается посмотреть, как современный международный терроризм оказывает воздействие на развитие, содержание и качественные характеристики выбранных больших трендов в мировой политике. При этом следует отметить, что цикличность наблюдается и в эволюции самого феномена терроризма. Известный терроролог Д. Рапопорт укрупненно выделял четыре основные исторические волны терроризма - анархистскую, антиколониальную, новую левую, религиозную [25]. Сегодня ученые выделяют «Пятую волну» терроризма, называя ее «полицентрическим или прокси-терроризмом» [4], который принципиально отличается от предшествующих видов по характеру, географическим масштабам, эффективности и степени используемости государствами для достижения геополитических целей.

Обозначенные тренды, на фоне эволюции терроризма, его усложнения и модификации с учетом аппликации экстремистами новейших технологий и приемов построения деятельности, актуализируют изучение влияния данного деструктивного феномена на основ- ные мегатренды мировой политики. Применяемый же автором в настоящей работе цикличный подход значим в части его аналитического применения, поскольку в рамках циклически-волновых концепций часто рассматриваются проблемы политического прогнозирования. В результате автор предлагает возможные сценарии борьбы с терроризмом в будущем и связанные с ними возможные векторы развития мирополитических мегатрендов.

Анализ. Исследование влияния терроризма на выбранные мегатренды требует концептуальных уточнений, учитывая то, что определения выбранных двух больших трендов вызывают дискуссии среди ученых и практиков. Однако в данной работе мы будем использовать наиболее известные дефиниции, не вдаваясь в подробности концептуальных дебатов относительно определений обозначенных явлений.

Влияние международного терроризма на глобализацию. Термин «глобализация» не имеет общепринятого определения. Хотя часто его связывают с экономической сферой, в том смысле, что глобализация привела к расширению, углублению и ускорению глобальной взаимозависимости. Однако глобализация выходит за рамки простого усиления экономического взаимодействия; она способствует быстрому перемещению в географическом пространстве не только товаров, услуг и людей, но и нематериальных ценностей вроде идей и культур. Превращение мира в «большую деревню» имеет безусловные плюсы, однако движение идей и материалов приводит к тому, что социально разнородные группы оказываются ближе друг к другу, что становится источником конфликтов, в том числе террористической направленности [15, p. 23]. Можно допустить, что в долгосрочной перспективе увеличение контактов между разнородными группами, их гомогенизация будет способствовать уменьшению предпосылок экстремистских идеологий [18], однако это прогноз достаточно отдаленной перспективы. На данный же момент в контексте угрозы терроризма глобализация формирует предпосылки насильственной практики.

В мирополитических исследованиях уже стало обычным утверждение о связи современного терроризма и глобализации. Большин- 


\section{ПРОГНОЗНЫЕ СЦЕНАРИИ ПОЛИТИЧЕСКИХ ТРАНСФОРМАЦИЙ}

ство профильных ученых указывают на то, что последняя способствовала расширению географических границ первого, укрупнению масштабов его деятельности и усилению влияния на глобальные процессы. Глобализация терроризма называется существенной чертой современного этапа развития данного феномена, который также проявляется беспрецедентным включением исламского компонента, «особенно в идеологическую базу многочисленных террористических структур» [5]. Возникновение нового, транснационального терроризма было детерминировано процессами глобализации и установлением нового мирового порядка. Одним из аспектов такого процесса является продвижение определенной модели глобализации, например, американской. Такая модель глобализации, особенно ее культурная массовизация на западный манер, несмотря на идеи Ф. Фукуямы, сторонника теории прямолинейного развития цивилизации, о конце истории, вызывает резкое неприятие в разных частях планеты, особенно в странах исламского цивилизационного ареала. Терроризм становится неким контрнаступлением на глобализацию, кризисным вариантом реакции на ее проблемы, которые в местных восточных контекстах усиливаются еще и горьким опытом колониального прошлого, несправедливым распределением экономических богатств по линии «Север - Юг» и т. д. Хотя здесь нужно отметить и мнение тех специалистов, которые уверены, что терроризм выступает против глобализации не как таковой, а таким девиантным способом пытается обратить внимание на исключение из процесса глобализации определенных обществ [22].

По мнению иранских специалистов С. Садатинэжод и В. Масохиби, глобализация в своей «утробе» вырастила свой антипод; ее процессы, направленные на размывание социально-культурных и иных границ, привели к противоположному результату. Началось повышение значимости элементов религии, этничности, расы и сохранения локальных культур. Развиваясь и получая социальную поддержку, эти процессы неизбежно оказываются по разные стороны баррикад с глобализацией, поскольку делают акцент на выделении групп по конкретным социальным признакам и на локализации, что вступает в противоречие с логикой развития глобализации [11]. Идеология современных террористов как раз использует эту диалектичную сущность глобализации для своих целей. Пример ИГ ${ }^{1}$ показывает, что современные террористы, используя определенные внешние атрибуты вестфальского государства, социально-экономические и технические достижения глобализации [3], на самом деле выступают против нее. Хотя отметим, что локальность насильственной идеологии радикальных исламистов носит временный характер; конечная цель наиболее амбициозных террористических формирований заключается в создании всемирного халифа$m a$, что представляет собой тоже некую форму глобализации.

С опорой на приведенные выше аргументы рассматривать взаимовлияние терроризма и глобализации можно и концепцией глокализации, которая объясняет во многом нелинеарный характер развития глобализации. Феномен глокализации, исходящий из логики сосуществования глобального и локального [27], не является предметом нашего анализа, однако он концептуально объясняет диалектичность природы глобализации, которой пользуются в своей идеология современные террористы. Более того, в основе глокализационных процессов лежит, в числе прочих, идея «справедливого мира», которая является популярной в нарративах современных террористов.

Вызовы современного терроризма актуализируют поиск и нахождение наиболее оптимальных долгосрочных стратегий предотвращения его деструктивного влияния, в том числе на глобализацию. Предлагаемые подходы, такие как в концепции «диалога цивилизации» бывшего иранского президента М. Хатами, часто кажутся нереалистичными. Однако в современных условиях широкий спектр акторов - от государственных до негосударственных, должны способствовать изучению и укреплению ценностей и взглядов, способных формировать конструктивные основы взаимодействия исламской идентичности и процессов глобализации, особенно в виртуальном мире, ставшем основным каналом распространения деструктивных нарративов. Несмотря на умозрительность, государства и международные институты должны продвигать глобальное межцивилизационное взаимо- 
действие, пропаганду значимости культурного разнообразия в мире, идею о возможности гармоничного сосуществования различных цивилизаций.

Терроризм и демократизация. Демократия и демократизация сегодня являются категориями, которые на практике претендуют на универсальность. Демократизация, по мнению известного американского ученого С. Хантингтона, происходит нелинейно, а волнами - за волной увеличения количества демократических государств в мире следует волна отката части из них в сторону авторитаризма [20]. Учитывая то, что демократизация является одним из главных мегатрендов современной мировой политики, актуальным будет осмысление влияния на него терроризма, потому что эти политические феномены часто «пересекаются» на практике, а «четвертая волна» демократизации, о которой пишут исследователи, часто носит характер силового навязывания демократического транзита [23]. При последнем подходе не только не усиливаются позиции демократии, а наоборот - возникает насильственная реакция, генерируются процессы де-демократизации.

В профильной научной литературе существуют, по крайней мере, два теоретических подхода к осмыслению взаимовлияния между демократией и терроризмом [16]. Сторонники первой точки зрения утверждают, что демократизация способствует уменьшению терроризма как явление, так как такая форма власти предлагает варианты выражения интересов среди граждан и поддерживает ненасильственное разрешение конфликтов. Такая логика в ее крайнем проявлении была характерна для администрации Дж. Буша-мл., который провозгласил демократию лучшим антиподом радикализма и террора, сделав продвижение демократии основным принципом так называемой Глобальной войны против терроризма. Такое поверхностное и «ложное умозаключение», по мнению К. Делакура, легло в основу оправдания смены американцами режимов в Афганистане и Ираке и постоянного давления на другие страны [17]. В итоге этой стратегии в названных странах, ее проявления в контексте «арабской весны», не только не уменьшилась угроза терроризма, но и наоборот, наблюдается его беспрецедентное развитие.

Взгляды второй когорты исследователей исходят, соответственно, из противоположной позиции, согласно которой политические и гражданские свободы, возросшие возможности и большая степень терпимости к разным политическим ценностям (иногда граничащими с экстремизмом) при демократических системах используются террористами для своих целей. Свобода передвижения и ассоциации, которыми пользуются в ареале демократических стран, обеспечивают возможности для террористических групп укорениться в уязвимых обществах и действовать против своего правительства или иностранных государств [26]. В таком контексте в некоторых сегментах мусульманского мира (Иран, Египет, Палестина) движение за демократию и свободные выборы приводило к торжеству различных по степени крайности исламистов. Хотя здесь, как справедливо отмечает Г. Мирский, для многих «умеренных исламистов идея ре-исламизации общества не равнозначна тенденции к установлению “муллократии”» [9].

Исходя из приведенных выше исследовательских позиций и наблюдений на практике, связь между терроризмом и демократизацией представляется диалектичной. Оба феномена оказывают влияние друг на друга, которое имеет как конструктивный, так и деструктивный эффект для динамики их развития. Признавая влияние международного терроризма на процессы демократизации, тем не менее, считать терроризм значительным фактором де-демократизации представляется достаточно гипертрофированной оценкой. Можно опираться на идеи С. Хантингтона, связавшего откатные волны с авторитаризмом, однако «варианты откатов могут быть разные, например, в архаизацию, распад государственности, которая приводит к формированию несостоявшихся государств» [6]. Такие тренды, в свою очередь, формируют благодатную почву для возникновения деструктивной насильственной идеологии современного терроризма. В этой связи, говоря о влиянии терроризма на такой мегатренд современности, как демократизация, можно выделить пять факторов, которые наиболее ярко проявляются на практике и оказывают влияние на динамику 


\section{ПРОГНОЗНЫЕ СЦЕНАРИИ ПОЛИТИЧЕСКИХ ТРАНСФОРМАЦИЙ}

данного больиого тренда в современную эпоху террористической активности.

Bo-nервых, терроризм становится удобным средством в руках лидеров различных государств для продвижения политики ограничения свободы и прав своих граждан. Расширительные трактовки феномена, включение в список террористов неугодных властям политических оппонентов, недостаточная прозрачность антитеррористических мероприятий создают опасную ситуацию, ликвидирующую альтернативу насильственному решению политических, социально-экономических проблем.

Bo-вmopblx, процессы демократизации в некоторых странах мусульманского мира привели к появлению на политической арене сил, склонных к применению методов терроризма в своей международной политике. С одной стороны, эти тенденции могут повысить популярность экстремистских нарративов, с другой привести к внешнему силовому свержению демократически избранных правителей, что чревато разрушением политической системы государства, долгосрочной дестабилизацией и возникновением новых, более сильных очагов международного терроризма.

$B$-mpeтьих, идеология современного международного терроризма противоречит ценностям демократического общества. Во многих слабых государствах активность террористических группировок становится препятствием на пути проведения демократических мероприятий, ставя под угрозу также верховенство законов государства. Именно в таких локальных масштабах терроризм становится значительным фактором де-демократизации. Репрессивные методы борьбы с террористами не всегда эффективны, особенно в нынешний век высоких технологий и виртуальной активности радикалов. Поэтому все актуальнее становится поиск и нахождение «мягких» инструментариев антитеррористической стратегии.

$B$-четвертых, некоторые исследователи считают важным параметром мегатренда демократизации развитие переговорных процессов в мире, поскольку сама демократия по сути представляется переговорным процессом [12]. В данном контексте проблема терроризма стала триггером очень широких и регулярных переговорных процессов как на глобальном, так и региональном уровнях. Однако проблемой остается то, что такой параметр демократизации, несмотря на видимое развитие, уязвим перед геополитическими интересами ведущих акторов мировой политики. Переговоры, конечно, способствуют определенным успехам тактического характера, однако в плане стратегического сотрудничества в борьбе с терроризмом геополитические мотивы оказываются выше, что негативно влияет на процессы демократизации. Примеры событий «арабской весны», сирийского кризиса или афганского конфликта с обилием переговорных процессов / площадок (часто с противоположными позициями) по их урегулированию это подтверждают.

И, в-nятых, само понятие «демократизация» из-за регулярного силового продвижения данного процесса дискредитируется. Особенно, когда такая политика в отношении отдельных стран мусульманского мира, наиболее уязвимого с точки зрения восприятия терроризма, носит достаточно селективный характер. Поэтому авторитарные режимы могут еще сильнее сопротивляться демократическим преобразованиям, а поддерживаемые извне группировки прибегать к использованию насилия для демократических преобразований. Этот опасный замкнутый круг обычно губителен для демократии в отдельно взятой стране или в целом регионе, а террористы в такой ситуации из проводников интересов внешних держав могут превратиться в значительных деструктивных акторов с высокой степенью самоорганизации и самодостаточности.

Возможные сценарии борьбы с терроризмом и динамика мегатрендов. Влияние международного терроризма на основные мегатренды современной мировой политики представляется очевидным, но достаточно сложным остается вопрос о том, насколько терроризм способен к возникновению «откатных» циклов больших трендов. Этот вопрос требует разработки сценариев развития такого взаимовлияния в будущем и определения состояния каждого из рассмотренных нами мегатрендов при конкретном сценарии. Нужно подчеркнуть, что мегатренды - это во многом изучение будущего, а разработка сценариев, пусть и кажущихся умозрительными, в 
этом контексте является логически адекватным исследовательским подходом. Автором предложены 2 больших сценария - позитивный и негативный, которые могут оставаться актуальными в течение 30-40 ближайших лет. Состояние каждого из мегатрендов при каждом сценарии представлено в схематичной форме (рис. 1-2).

1. Позитивный сиенарий.

В рамках позитивного сценария автор выделяет идеалистический и реалистический сценарии. При долгосрочном позитивноидеалистическом сценарии постепенно возникнут общества, стремящиеся к моральному совершенству, в которых идеология терроризма станет неприемлемой / невостребованной. Государство и другие акторы будут спо- собны на глобальном уровне решить вопросы терроризма. Несмотря на привлекательность, данный сценарий сверхоптимистичен и глубоко утопичен.

Позитивно-реалистический сиенарий предполагает, что государства, осознавая угрозу терроризма, будут наращивать антитеррористическое сотрудничество, поскольку угроза насильственного экстремизма останется ключевой проблемой для национальной безопасности большинства из них. Можно ожидать возникновение относительно эффективной глобальной антитеррористической структуры, занимающейся как превентивными вопросами, так и гармонизацией политики разных стран в политическом, правовом, культурном и других аспек-

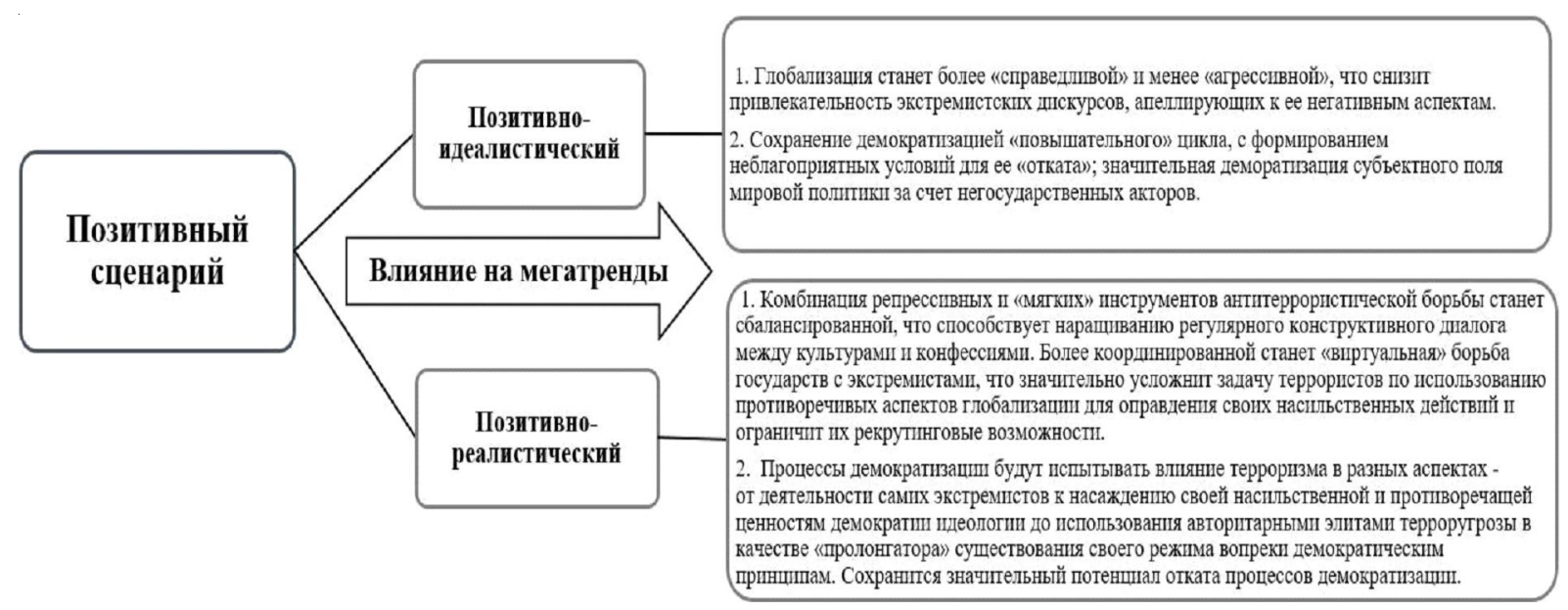

Рис. 1. Позитивный сценарий борьбы с терроризмом и динамика мегатрендов

Fig. 1. Positive counterterrorism scenario and the dynamic of megatrends

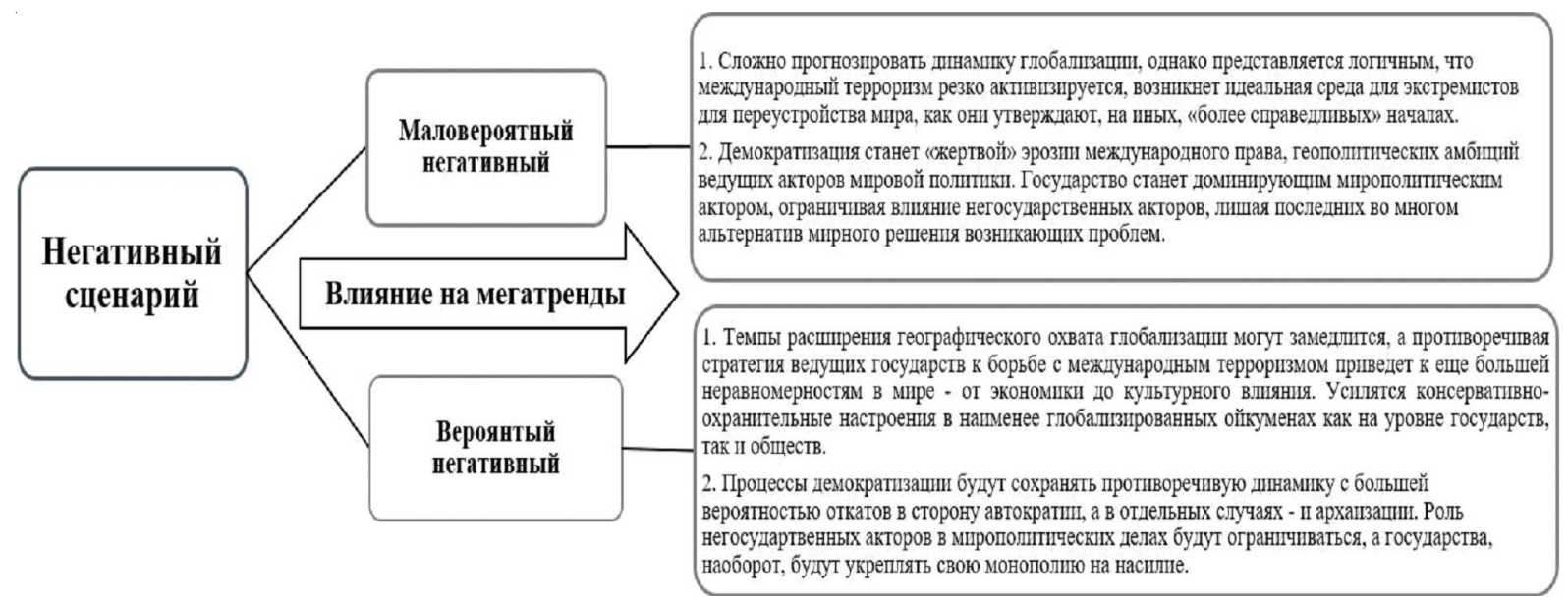

Рис. 2. Негативный сценарий борьбы с терроризмом и динамика мегатрендов

Fig. 2. Negative counterterrorism scenario and the dynamic of megatrends 


\section{ПРОГНОЗНЫЕ СЦЕНАРИИ ПОЛИТИЧЕСКИХ ТРАНСФОРМАЦИЙ}

тах борьбы с терроризмом. Идейно-правовой основой такого института может стать Глобальная контртеррористическая стратегия ООН. В рамках данного сценария государства могут использовать как «жесткосиловые», так и «мягкие» инструменты борьбы с международным терроризмом.

«Жесткосиловое» измерение.

- Главный акцент будет сделан на усилении центральной роли ООН, о которой регулярно заявляет Россия. Параллельно будет активизировано антитеррористическое сотрудничество в рамках и между другими крупными региональными институтами, такими как НАТО, ШОС, ОДКБ и др. Будут приняты международные концептуально-правовые акты и программы с участием значительного числа государств мира, направленные на борьбу с терроризмом через лишение его ресурсов - финансовых, технических и т. д. Пример деятельности Группы разработки финансовых мер борьбы с отмыванием денег (ФАТФ) показывает, что такие возможности у международного сообщества существуют.

«Мягкая сила».

- Большое внимание будет уделено условиям возникновения и распространения терроризма и борьбы с ними. Возрастет роль религиозных учреждений в исламских странах, особенно если сохранится позитивная динамика их интернационализации - развития сотрудничества с разными научноаналитическими центрами Запада и других государств. Такой регулярный диалог способен нивелировать значимость религиозноэкстремистских нарративов и усилить влияние позитивно мыслящих религиозных деятелей в уязвимых перед идеологией терроризма обществах.

- Предсказуемым представляется наращивание использования технологии искусственного интеллекта в антитеррористической борьбе. Можно ожидать сотрудничества государств в проведении совместной «виртуальной» борьбы с террористами, как это наблюдается сегодня на примере работы НАТО, ШОС и ОДКБ. Благодаря технологиям ИИ голоса авторитетных религиозных богословов и организаций будут постоянно «глушить» террористический дискурс, ограничивая вербовочные усилия радикалов.

\section{2. Негативный сиенарий.}

Негативный сценарий борьбы с терроризмом тоже представлен двумя возможными вариантами развития событий: маловероятный негативный и вероятный негативный. При первом сценарии прогнозируем, что в ближайшие десятилетия эрозия международного права и критическое повышение градуса противоречий между ведущими центрами влияния в мире могут привести к дисфункции системы международных отношений и анархии в мировой политике, что станет импульсом для развития терроризма. Данный сценарий представляется самым неблагоприятным развитием событий.

Вероятный негативный сиенарий предполагает, что глобального и всеобъемлющего консенсуса в борьбе с терроризмом между государствами не будет. Нормой станет низкий уровень антитеррористического взаимодействия. Для некоторых государств использование экстремистских группировок станет инструментом достижения (гео)политических целей в гораздо большей степени и открытой форме, чем это иногда наблюдается сегодня. Особенности борьбы с ИГ, вариативность подходов к классификации террористических группировок в мире, тенденция к взаимному обвинению крупных держав друг друга в оказании помощи террористам и другие примеры делают этот прогноз достаточно реалистичным. Реализация такого сценария «продлит» жизнь терроризму на еще несколько десятилетий, а текущая динамика его развития еще больше усилится.

Результаты. Вызовы современного терроризма для гармоничного человеческого общежития требуют изучения влияния данного феномена на основные тренды мирового развития. Проведенный нами анализ показал, что терроризм в разной степени влияет на динамику развития глобализации и демократизации, хотя установление существенности такой связи отличается - в случае с глобализацией это не так просто, как, например, с процессами демократизации.

На уровне теоретизирования в контексте поиска идеологических корней терроризма легко находится взаимосвязь между ним и глобализацией. Современный терроризм в условиях отсталости определенных обществ, их слабой включенности в глобальные процессы 
стал формой насильственного установления «справедливости». Кажется, что идеология современных террористов исключает всякую глобализацию, однако в конечном счете исламские экстремисты стремятся к «своей» глобализации, которую ошибочно видят линейно-поступательным процессом.

Демократизация, несмотря на признание ее в качестве наиболее желаемой формы правления, удобной в том числе для ненасильственного разрешения конфликтов, достаточно уязвима перед современным терроризмом. Во многом в сохранении терроризма или его угрозы заинтересованы авторитарно настроенные режимы, так как обозначенная угроза позволяет таким правительствам удерживать власть. Однако, как показывает практика, в некоторых странах Востока демократизация, наоборот, может привести к власти радикальных исламистов, потенциальных симпатизантов или спонсоров международных террористов. В контексте ближневосточного региона, а еще шире - потенциально Центральной Азии и Южной Азии, выбор в дилемме демократизация или сохранение авторитарных режимов крайне сложен. Имеющийся опыт внешнего вмешательства с навязыванием демократии привели к росту терроризма и значительным кризисам государственности в обширном регионе. Такая стратегия, нарушающая процесс естественного «прихода» демократии с импульсами изнутри страны, привела к дискредитации демократизации как феномена и концепта. Данный момент широко используется современными террористами в их пропаганде для обоснования своей деструктивной деятельности. Представляется, что в обозримом будущем противоречивая взаимосвязь терроризма и демократизации будет сохраняться.

В целом наблюдения за нынешними тенденциями активности террористов показывают, что в любом случае терроризм останется значительным фактором в эволюции глобализации и демократизации, а осмысление такого взаимовлияния требует регулярного научного внимания.

\section{ПРИМЕЧАНИЕ}

1 Деятельность организации запрещена на территории РФ.

\section{СПИСОК ЛИТЕРАТУРЫ}

1. Архаизация государства: роль современных информационных технологий / М. М. Лебедева, М. В. Харкевич, Е. С. Зиновьева, Е. Н. Копосова // Полис. Политические исследования. - 2016. - № 6. C. 22-36.-DOI: https://doi.org/10.17976/jpps/2016.06.03.

2. Галиуллин, М. 3. Мегатренды мировой политики и глобальная безопасность / М. 3. Галиуллин, Я. Я. Гришин. - Казань : Изд-во Казан. ун-та, 2017. $-75 \mathrm{c}$.

3. Голунов, С. В. Террористический «халифат» как квазигосударство: проблема концептуализации / С. В. Голунов // Полития. - 2020. № 2 (97). - C. 87-103. -DOI: https://doi.org/10.30570/ 2078-5089-2020-97-2-87-103.

4. Дзлиев, М. И. Внимание, новая волна терроризма - «полицентрическая» / И. М. Дзлиев // Стратегические приоритеты. -2018 . - № 3 (19). - С. 74-88.

5. Добаев, И. «Новый терроризм»: глобализация и социально-экономическое расслоение / И. Добаев, А. Добаев // Мировая экономика и международные отношения. - 2009. - № 5. - С. 114-120.

6. Ильин, В. В. Структурность политосферы / В. В. Ильин // Полис. Политические исследования. -1995 . - № 1. - С. 98-99.

7. Лебедева, М. Современные мегатренды мировой политики / М. Лебедева // Мировая экономика и международные отношения. - 2019. T. 63, № 9. - C. 29-37. - DOI: https://doi.org/10.20542/ 0131-2227-2019-63-9-29-37.

8. Мегатренды. Основные траектории эволюции мирового порядка в XXI веке / под ред. Т. А. Шаклеиной и А. А. Байкова. - Изд. второе, испр. и доп. - М. : Аспект Пресс, 2014. - 448 с.

9. Мирский, Г. И. Исламский мир: «отстающее развитие» и мусульманский радикализм / Г. И. Мирский // Мировая экономика и международные отношения. - 2008. - № 8. - С. 89-103.

10. Пантин, В. И. Волны политической модернизации в истории России. К обсуждению гипотезы / В. И. Пантин, В. В. Лапкин // Полис. Политические исследования. - 1998. - № 2. - С. 39-51.

11. Садатинэжод, С. Взаимовлияние глобализации и экстремизма / С. Садатинэжод, В. Масохиби // Фаслнома-е сиясати хоричи. - 2017. - № 3. - С. 121162. - (На перс. яз.).

12. Сергеев, В. М. Демократия как переговорный процесс / В. М. Сергеев. - М. : МОНФ, 1999. - 147 с.

13. Тамбиева, 3. С. Нелинейные процессы социального развития общества : автореф. дис. ... канд. филос. наук / Тамбиева Зурида Сафарбиевна. Ставрополь, 2005. $-154 \mathrm{c}$.

14. Baylis, J. The Globalization of World Politics, an Introduction to International Relations / J. Baylis, S. Smith. - N. Y. : Oxford University Press, 2005. -481 p. 
15. Brynjar, L. Globalisation and the Future of Terrorism: Patterns and Predictions / L. Brynjar. London; New York : Routledge, 2005. - 259 p.

16. Chenoweth, E. The Inadvertent Effects of Democracy on Terrorist Group Emergence/E. Chenoweth // Discussion Paper of the Belfer Center for Science and International Affairs. - 2006. - № 6. - 31 p.

17. Dalacoura, K. Islamist Terrorism and Democracy in the Middle East / K. Dalacoura. - Cambridge, UK : Cambridge University Press, 2011. - 224 p.

18. Donald, B. The Geometry of Terrorism / B. Donald // Sociological Theory. - 2004. - Vol. 22, № 1. - P. 14-25.

19. Five Megatrends and Their Implications for Global Defense \& Security // PwC. - November 2016. $-27 \mathrm{p}$.

20. Huntington, S. Democracy's Third Wave / S. Huntington // The Journal of Democracy. - 1991. № 2. - P. 12-34.

21. Kaldor, M. Cycles in World Politics / M. Kaldor // International Studies Review. - 2018. - Vol. 20, iss. 2. P. 214-222. - DOI: https://doi.org/10.1093/isr/viy038.

22. Khan, A. Globalization and terrorism: an overview / A. Khan, M. A. Ruiz Estrada // Quality \& Quantity: International Journal of Methodology. 2016. - Vol. 51 (4). - P. 1811-1819. - DOI: https:// doi.org/10.1007/s11135-016-0367-5.

23. McFaul, M. The Fourth Wave of Democracy and Dictatorship: Noncooperative Transitions in the Postcommunist World / M. McFaul // World Politics. 2002. - Vol. 54, № 2. - P. 212-244.

24. Naisbitt, J. Megatrends: ten new directions transforming our lives / J. Naisbitt. - N. Y. : Warner Books, 1982. $-290 \mathrm{p}$.

25. Rapoport, C. David. The Four Waves of Rebel Terror and September 11 / David C. Rapoport // The New Terrorism: Characteristics, Causes and Controls / ed. by Charles W. Kegley Jr. - New Jersey : Prentice Hall, 2003. - P. 36-52.

26. Schmid A. Terrorism and Democracy // Terrorism and Political Violence. - 1992. - Vol. 4, № 4. - P. 14-25.

27. Swyngedouw, E. Globalisation or 'glocalisation'? Networks, territories and rescaling / E. Swyngedouw // Cambridge Review of International Affairs. - 2004. - № 17 (1). - P. 25-48. DOI: https:// doi.org/10.1080/0955757042000203632.

\section{REFERENCES}

1. Lebedeva M.M., Kharkevich M.V., Zinoveva E.S., Koposova E.N. Arkhaizatsiia gosudarstva: rol sovremennykh informatsionnykh tekhnologii [State Archaization: The Role of Modern Information Technologies]. Polis. Politicheskie issledovaniia [Polis. Political Studies Journal], 2016, no. 6, pp. 22-36. DOI: https://doi.org/10.17976/jpps/ 2016.06.03

2. Galiullin M.Z., Grishin Ia.Ia. Megatrendy mirovoi politiki i globalnaia bezopasnost [World Politics Megatrends and Global Security]. Kazan, Izd-vo Kazanskogo universiteta, 2017. 75 p.

3. Golunov S.V. Terroristicheskii «khalifat» kak kvazigosudarstvo: problema kontseptualizatsii [Terrorist "Caliphate" as a Quasi-State: Problem of Conceptualization]. Politiia [Politeia], 2020, no. 2 (97), pp. 87-103. DOI: https://doi.org/10.30570/2078-50892020-97-2-87-103.

4. Dzliev M.I. Vnimanie, novaia volna terrorizma «politsentricheskaia» [Attention, New Wave of Terrorism - «Polycentric»]. Strategicheskie prioritety [Strategic Priorities], 2018, no. 3 (19), pp. 74-88.

5. Dobaev I., Dobaev A. «Novyi terrorizm»: globalizatsiia i sotsialno-ekonomicheskoe rassloenie ["New Terrorism": Globalization and Socio-Economic Stratification]. Mirovaia ekonomika i mezhdunarodnye otnosheniia [World Economy and International Relations], 2009, no. 5, pp. 114-120.

6. Ilin V.V. Strukturnost politosfery [Structurality of the Politosphere]. Polis. Politicheskie issledovaniia [Polis. Political Studies Journal], 1995, no. 1, pp. 98-99.

7. Lebedeva M. Sovremennye megatrendy mirovoi politiki [Modern Megatrends of World Politics]. Mirovaia ekonomika i mezhdunarodnye otnosheniia [World Economy and International Relations], 2019, vol. 63, no. 9, pp. 29-37. DOI: https:// doi.org/10.20542/0131-2227-2019-63-9-29-37.

8. Shakleina T.A., Baikov A.A., eds. Megatrendy. Osnovnye traektorii evoliutsii mirovogo poriadka $v$ XXI veke [Megatrends. The Main Trajectories of the Evolution of the World Order in the $21^{\text {st }}$ Century]. $2^{\text {nd }}$ ed. Moscow, Aspekt Press Publ., 2014. 448 p.

9. Mirskii G.I. Islamskii mir: «otstaiushchee razvitie» i musulmanskii radikalizm [Islamic World: "Lagging Development" and Muslim Radicalism]. Mirovaia ekonomika i mezhdunarodnye otnosheniia [World Economy and International Relations], 2008, no. 8, pp. 89-103.

10. Pantin V.I., Lapkin V.V. Volny politicheskoi modernizatsii v istorii Rossii. K obsuzhdeniiu gipotezy [Waves of Political Modernization in the History of Russia. To the Discussion of the Hypothesis]. Polis. Politicheskie issledovaniia [Polis. Political Studies Journal], 1998, no. 2, pp. 39-51.

11. Sadatinezhod S., Masokhibi V. Vzaimovliianie globalizatsii i ekstremizma [The Mutual Influence of Globalization and Extremism]. Faslnoma-e siiasati khorichi [Foreign Policy Quarterly], 2017, no. 3, pp. 121-162. (In Persian).

12. Sergeev V.M. Demokratiia kak peregovornyi protsess [Democracy as a Negotiation Process]. Moscow, MONF, 1999. $147 \mathrm{p}$. 
13. Tambieva Z.S. Nelineinye protsessy sotsialnogo razvitiia obshchestva: avtoref. diss. ... kand. filos. nauk [Nonlinear Processes of Social Development of Society: Cand. philos. sci. abs. diss.]. Stavropol, 2005. $154 \mathrm{p}$.

14. Baylis J., Smith S. The Globalization of World Politics, an Introduction to International Relations. New York, Oxford University Press, 2005. 481 p.

15. Brynjar L. Globalisation and the Future of Terrorism: Patterns and Predictions. London and New York, Routledge, 2005. 259 p.

16. Chenoweth E. The Inadvertent Effects of Democracy on Terrorist Group Emergence. Discussion Paper of the Belfer Center for Science and International Affairs, 2006, no. 6.31 p.

17. Dalacoura K. Islamist Terrorism and Democracy in the Middle East. Cambridge, UK, Cambridge Univ. Press, 2011.224 p.

18. Donald B. The Geometry of Terrorism. Sociological Theory, 2004, vol. 22, no. 1, pp. 14-25.

19. Five Megatrends and Their Implications for Global Defense \& Security. $P w C$, November 2016. $27 \mathrm{p}$.

20. Huntington S. Democracy's Third Wave. The Journal of Democracy, 1991, no. 2, pp. 12-34.
21. Kaldor M. Cycles in World Politics. International Studies Review, 2018, vol. 20, iss. 2, pp. 214-222. DOI: https://doi.org/10.1093/isr/viy038.

22. Khan A., Ruiz Estrada M.A. Globalization and terrorism: an overview. Quality \& Quantity: International Journal of Methodology, Springer, 2016, vol. 51 (4), pp. 1811-1819. DOI: https://doi.org/10.1007/ s11135-016-0367-5.

23. McFaul M. The Fourth Wave of Democracy and Dictatorship: Noncooperative Transitions in the Postcommunist World. World Politics, 2002, vol. 54, no. 2. pp. 212-244.

24. Naisbitt J. Megatrends: Ten New Directions Transforming Our Lives. New York, Warner Books, 1982. 290 p.

25. Rapoport C. David. The Four Waves of Rebel Terror and September 11. Charles W. Kegley Jr., ed. The New Terrorism: Characteristics, Causes and Controls. New Jersey, Prentice Hall, 2003, pp. 36-52.

26. Schmid A. Terrorism and Democracy. Terrorism and Political Violence, 1992, vol. 4, no. 4, pp. 14-25.

27. Swyngedouw E. Globalisation or 'Glocalisation'? Networks, Territories and Rescaling. Cambridge Review of International Affairs, 2004, no. 17 (1), pp. 25-48. DOI: https://doi.org/10.1080/0955757042000203632.

\section{Information About the Author}

Hasan R. Jabbarinasir, Candidate of Sciences (Politics), Senior Lecturer, Department of IndoIranian and African Languages, MGIMO University MFA Russia, Prosp. Vernadskogo, 76, 119454 Moscow, Russian Federation, jabbari@inno.mgimo.ru, https://orcid.org/0000-0003-3181-6101

\section{Информация об авторе}

Хасан Реза Джаббаринасир, кандидат политических наук, старший преподаватель кафедры индо-иранских и африканских языков, Московский государственный институт международных отношений (университет) МИД России, просп. Вернадского, 76, 119454 г. Москва, Российская Федерация, jabbari@inno.mgimo.ru, https://orcid.org/0000-0003-3181-6101 